\title{
Fatal parasite-induced enteritis and typhlocolitis in horses in Southern Brazil
}

\author{
Enterites e tiflocolites parasitárias fatais em equinos no Sul do Brasil

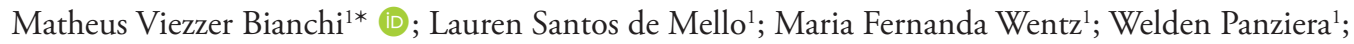 \\ João Fábio Soares ${ }^{2}$ (D); Luciana Sonne ${ }^{1}$; David Driemeier ${ }^{1}$; Saulo Petinatti Pavarini ${ }^{1}$
}

\begin{abstract}
${ }^{1}$ Setor de Patologia Veterinária, Departamento de Patologia Clínica Veterinária, Faculdade de Veterinária, Universidade Federal do Rio Grande do Sul - UFRGS, Porto Alegre, RS, Brasil

${ }^{2}$ Laboratório de Protozoologia e Rickettsioses Vetoriais, Departamento de Patologia Clínica Veterinária, Faculdade de Veterinária, Universidade Federal do Rio Grande do Sul - UFRGS, Porto Alegre, RS, Brasil
\end{abstract}

Received March 26, 2019

Accepted June 25, 2019

\begin{abstract}
Diseases related to the alimentary system are the main cause of death in horses. This retrospective study aimed to describe the pathological findings of fatal parasite-induced enteritis and typhlocolitis caused by cyathostominae, Eimeria leuckarti, Balantidium coli, and Strongyloides westeri in horses. The records of parasite-induced intestinal lesions in horses necropsied in Southern Brazil between 2005 and 2017 were reviewed. Ten horses had fatal parasitic enteritis and/or typhlocolitis, and the main causes were: cyathostominae typhlocolitis $(6 / 10)$, E. leuckarti enteritis $(1 / 10)$, S. westeri enteritis (1/10), B. coli colitis related to cyathostominae (1/10), and infection by multiple agents $(1 / 10)$. Cyathostominae typhlocolitis showed marked mucosal thickening, with multifocal elevated nodules containing tangled filiform parasites. Microscopic examination revealed that the mucosa and submucosa had encysted parasitic structures surrounded by eosinophilic and granulomatous inflammation. E. leuckarti enteritis was microscopically characterized by macrogamonts, microgamonts, and oocysts inside the host cells. S. westeri enteritis showed microscopic atrophy of the villi with numerous mucosal encysted parasitic structures. B. coli typhlocolitis showed severe diffuse mucosal reddening, with microscopic superficial mucosal necrosis associated with multiple protozoan trophozoites. Fatal parasite-induced enteritis and typhlocolitis are important causes of death in horses in Southern Brazil.
\end{abstract}

Keywords: Parasitic diseases, colic, cyathostominae, Eimeria leuckarti, Strongyloides westeri, Balantidium coli.

\section{Resumo}

Doenças relacionadas ao sistema alimentar são as principais causas de morte em equinos. Esse estudo teve o objetivo de descrever aspectos patológicos de enterites e tiflocolites parasitárias fatais por ciatostomíneos, Eimeria leuckarti, Balantidium coli e Strongyloides westeri, em equinos. Foi revisado o banco de dados de lesóes intestinais parasitárias em equinos necropsiados de 2005 a 2017, no Sul do Brasil. Dez equinos apresentaram enterite e/ou tiflocolite parasitária fatal, e as principais foram: tiflocolite por ciatostomíneos (6/10), enterite por E. leuckarti $(1 / 10)$, enterite por $S$. westeri $(1 / 10)$, colite por $B$. coli com ciatostomíneos (1/10), e infecção por múltiplos agentes (1/10). A tiflocolite por ciatostomíneos exibia acentuado espessamento da mucosa, com nódulos multifocais elevados contendo parasitas filiformes. Microscopicamente, a mucosa e submucosa apresentavam estruturas parasitárias encistadas envoltas por inflamação eosinofílica e granulomatosa. A enterite por E. leuckarti era caracterizada microscopicamente por macrogamontes, microgamontes e oocistos no interior de células do hospedeiro. Microscopicamente, a enterite por $S$. westeri apresentava atrofia de vilosidades com numerosas estruturas parasitárias encistadas na mucosa. A tiflocolite por B. coli exibia avermelhamento acentuado difuso da mucosa, e microscopicamente necrose superficial associada a múltiplos trofozoítos protozoáricos. Enterites e tiflocolites fatais parasitárias são importantes causas de morte em equinos no Sul do Brasil.

Palavras-chave: Doenças parasitárias, cólica, ciatostomíneos, Eimeria leuckarti, Strongyloides westeri, Balantidium coli.

\footnotetext{
*Corresponding author: Matheus Viezzer Bianchi. Setor de Patologia Veterinária, Departamento de Patologia Clínica Veterinária, Faculdade de Veterinária, Universidade Federal do Rio Grande do Sul - UFRGS, Av. Bento Gonçalves, 9090, CEP 90040-060, Porto Alegre, RS, Brasil. e-mail: matheusviezzerb@hotmail.com
} 


\section{Introduction}

The horse industry is an important part of the Brazilian economy, with an effective herd size of 5.5 million animals, and the second largest population of horses in Brazil $(553,191$ horses) is located in Rio Grande do Sul state (IBGE, 2017). The industry is estimated to generate an annual economic flow of R\$ 16.15 billion and to generate approximately 3.000.000 direct and indirect jobs (BRASIL, 2016). Diseases related to the alimentary system are the main cause of death in horses in this state (PIEREZAN et al., 2009b), as in other countries (BAKER \& ELLIS, 1981). Among these diseases, displacements of the intestines, obstructions, impactions, perforations, and ruptures are the main cause of death in horses (BAKER \& ELLIS, 1981; PIEREZAN et al., 2009b).

Gastrointestinal parasites are also one of the most important problems in developing countries such as Brazil (PEREIRA \& VIANNA, 2006). However, most studies have only addressed the general occurrence of gastrointestinal parasites in equines through fecal examination (MARCOLONGO-PEREIRA et al., 2014; PEREIRA \& VIANNA, 2006; SHEFERAW \& ALEMU, 2015). Moreover, a few studies have described the clinical and pathological findings related to fatal larval cyathostomiasis (BODECEK et al., 2010; PIEREZAN et al., 2009a), Strongyloides westeri enteritis (LUCENA et al., 2012) and Balantidium coli colitis (HEADLEY et al., 2008). Nevertheless, recent studies have expressed concerns regarding the increasing prevalence of cyathostomins, their potential pathogenicity, and anthelmintic drug resistance (CORNING, 2009; LOVE et al., 1999). Thus, these parasites continue to pose a potential threat to equine health and are becoming increasingly difficult to control (NIELSEN \& LYONS, 2017).

Therefore, the aim of this study was to describe the gross and microscopic findings related to fatal parasite-induced enteritis and typhlocolitis caused by cyathostominae, Eimeria leuckarti, B. coli and $S$. westeri in horses.

\section{Materials and Methods}

A retrospective study of the necropsy database of horses was conducted to search for records of parasite-induced lesions involving the small and large intestines detected between January 2005 and December 2017 at the veterinary pathology laboratory. These cases were grouped into non-fatal (incidental) and fatal conditions, and only cases of fatal parasite-induced enteritis and typhlocolitis were selected. All horses studied were from the metropolitan area of Porto Alegre, Rio Grande do Sul state. Information regarding the clinical signs, seasonal occurrence, age, sex, breed, and gross lesions were retrieved from the necropsy database. Paraffin-embedded tissues of the selected cases were routinely processed for histological examination, and stained using hematoxylin and eosin. The Gordon \& Whitlock (1939) technique was performed post-mortem in two cases (horses \#4 and \#5) with three replicates for each horse. Histological classification of cyathostominae larval stages was based on previous studies (NIELSEN et al., 2015; PIEREZAN et al., 2009a), with larger larvae classified as late L3/L4 and small larvae as early L3.

\section{Results}

Between January 2005 and December 2017, 654 horses were necropsied at the veterinary pathology laboratory. Of these, 10 horses had fatal parasitic enteritis and/or typhlocolitis. The main cause for these were cyathostominae typhlocolitis in six cases, and E. leuckarti enteritis, $S$. westeri enteritis and B. coli colitis associated with cyathostominae in one case each. One of the horses was infected by multiple agents, including large amounts of $S$. westeri and E. leuckarti in the small intestine and few cyathostominae in the large intestine. Age, sex, breed and seasonal occurrence of fatal parasite-induced enteritis and typhlocolitis in each horse are described in Table 1. Clinical signs associated with the conditions diagnosed are provided in Table 2 .

Cyathostominae typhlocolitis was grossly characterized in all six cases by abundant greenish liquid and fetid content in both the cecum and large colon, with large amounts of filiform reddish free parasites measuring $1 \mathrm{~cm}$ in length in three cases (Figure 1A), and marked thickening of the mucosa in all cases. The mucosal surface had multifocal to coalescent red pinpoint areas (petechial hemorrhages) in addition to multifocal elevated nodules measuring up to $3 \mathrm{~mm}$ in diameter (Figure 1B), which occasionally had erosions on the surface ( $3 / 6$ cases) and commonly contained tangled filiform parasites on the cut surface, measuring 0.5 to $1 \mathrm{~cm}$ in length (Figure $1 \mathrm{C}$ ). In addition, moderate to severe colonic and cecal lymphadenomegaly was observed in all six cases. Microscopic examination in all cases revealed that the cecum and large colon had their mucosa and submucosa disrupted by moderate to large amounts of encysted parasitic structures surrounded by an eosinophilic and granulomatous inflammatory response (Figure 1D). These parasitic structures were

Table 1. Age, breed, sex and seasonal occurrence of fatal parasite-induced enteritis and typhlocolitis in horses, from Porto Alegre, RS, Brazil.

\begin{tabular}{cccccc}
\hline Horse & Age & Breed & Sex & Seasonal occurrence & Condition diagnosed \\
\hline 1 & 1.4 years old & Criollo & $\mathrm{M}$ & Autumn & CT \\
2 & 1.5 years old & Criollo & NI & Spring & CT \\
3 & 10 months old & Criollo & F & Spring & CT \\
4 & 1 year old & Mixed breed & Spring & CT \\
5 & 1 year old & Mixed breed & F & Spring & CT \\
6 & 7 months old & Criollo & M & Winter & EE \\
7 & 20 years old & Mixed breed & M & Spring & SwE \\
8 & 1 month old & Criollo & F & Spring & BcT and CT \\
9 & 2 months old & Quarter horse & M & Autumn & SwE, EE and CT \\
10 & 4 months old & Mangalarga marchador &
\end{tabular}

$\mathrm{M}=$ male; $\mathrm{F}$ = female; $\mathrm{NI}$ = not informed $; \mathrm{CT}=$ Cyathostominae typhlocolitis; $\mathrm{EE}=$ Eimeria leuckarti enteritis; SwE = Strongyloides westeri enteritis; BcT = Balantidium coli typhlocolitis. 
Table 2. Clinical signs associated to fatal parasite-induced enteritis and typhlocolitis in horses, from Porto Alegre, RS, Brazil.

\begin{tabular}{ccl}
\hline Horse & Condition diagnosed & \multicolumn{1}{c}{ Clinical signs } \\
\hline 1 & CT & Chronic liquid diarrhea \\
2 & $\mathrm{CT}$ & Profuse diarrhea \\
3 & $\mathrm{CT}$ & Diarrhea, pale mucous membranes, weight loss and weakness \\
4 & $\mathrm{CT}$ & Liquid diarrhea, abdominal increase, inappetence, polydipsia and weakness \\
5 & $\mathrm{CT}$ & Liquid diarrhea, abdominal increase, inappetence, polydipsia and weakness \\
6 & $\mathrm{CT}$ & Diarrhea, pale mucous membranes, bilateral ocular opacity and blindness \\
7 & $\mathrm{EE}$ & Severe weight loss (cachexia) \\
8 & SwE & Chronic liquid diarrhea, fever, apathy and dehydration \\
9 & $\mathrm{BcT}$ and CT & Inappetence, apathy and diarrhea \\
10 & SwE, EE and CT & Sudden death \\
\hline
\end{tabular}

CT = Cyathostominae typhlocolitis; $\mathrm{EE}=$ Eimeria leuckarti enteritis; SwE = Strongyloides westeri enteritis; BcT = Balantidium coli typhlocolitis .

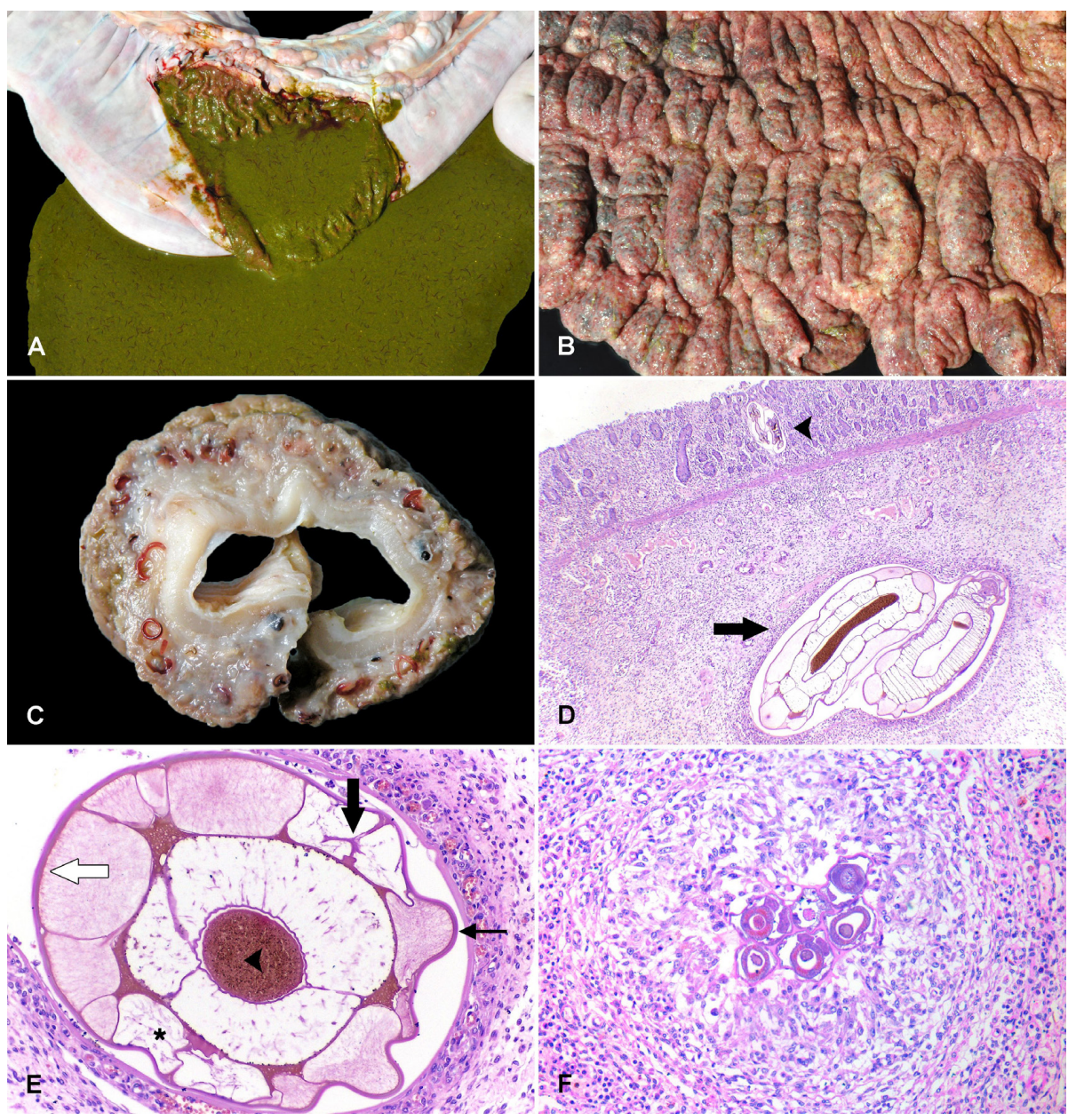

Figure 1. Gross and microscopic findings of cyathostominae typhlocolitis. (A) The large colon has an abundant greenish liquid content, with uncountable filiform reddish free parasites measuring $1 \mathrm{~cm}$ in length; (B) The mucosa is markedly thickened with multifocal to coalescent red pinpoint areas (petechial hemorrhages) in addition to multifocal elevated nodules; (C) On the cut surface, these nodules have tangled filiform reddish parasites inside; (D) The mucosa and submucosa of the large colon are disrupted by encysted parasitic structures: late L3 and L4 parasites (arrow) and early L3 parasites (arrowhead). Hematoxylin and eosin (H\&E), 40× magnification; (E) Late L3 and L4 parasites have a thick eosinophilic cuticle (thin arrow), thin platymyarian musculature (empty arrow), finely vacuolated lateral cords (asterisk), prominent internal cuticular crests (thick arrow), and multinucleate intestines with a brush border in the apex and brown granular content (arrowhead). H\&E, 200× magnification; (F) The submucosa is expanded by an eosinophilic and granulomatous inflammatory response that surrounds the parasitic structures. H\&E, 200× magnification.

characterized by: multiple late L3 and L4 parasites (300-400 $\mu \mathrm{m}$ in diameter), which were composed of a thick eosinophilic cuticle, thin platymyarian musculature, finely vacuolated lateral cords, prominent internal cuticular crests, and multinucleate intestines with a brush border in the apex and brown granular content (Figure 1E), as well as few early L3 parasites (80-100 $\mu \mathrm{m}$ in diameter), which were only located in the mucosa, were composed of a thick eosinophilic cuticle, and had a digestive tract with granular basophilic cells. The submucosa was expanded because of a similar inflammatory response that surrounded the parasitic structures, and showed 
severe edema, marked muscle layer hypertrophy of the arterioles, moderate lymphoid hyperplasia with random necrosis, and mild to moderate thrombosis (Figure $1 \mathrm{~F}$ ). The superficial erosions on gross observation (3/6 cases) corresponded to focal areas of mucosal ulceration with associated hemorrhage and fibrin deposition. Frequently, the muscular layer of the mucosa was ruptured by the emergence of the encysted larvae, and the mucosa was eroded. Marked lymphoid hyperplasia and erythrophagocytosis were also observed on the mesenteric lymph nodes. Surprisingly, the eggs per gram of feces (EPG) of horses \#4 and \#5 were negative on all three replicates. Moreover, a direct analysis of the larvae observed in the luminal content of these two horses revealed that only L4 parasites were present, and the adult forms were absent.

Gross abnormalities of $E$. leuckarti enteritis were only evidenced by the abundant liquid content in the small intestine, in addition to severe cachexia, pale mucous membranes, dehydration, and serous fat atrophy in the pericardial adipose tissue. Microscopic examination revealed that the villi of the jejunum and ileum had mild atrophy and multiple parasitic structures at distinct stages (macrogamonts, microgamonts, and oocysts) inside the hypertrophied host cells, which were flattened (signet-ring appearance) at the apex (Figure 2A). Macrogamonts were round, measured up to $80 \mu \mathrm{m}$ in diameter, and contained multiple peripheral eosinophilic round granules

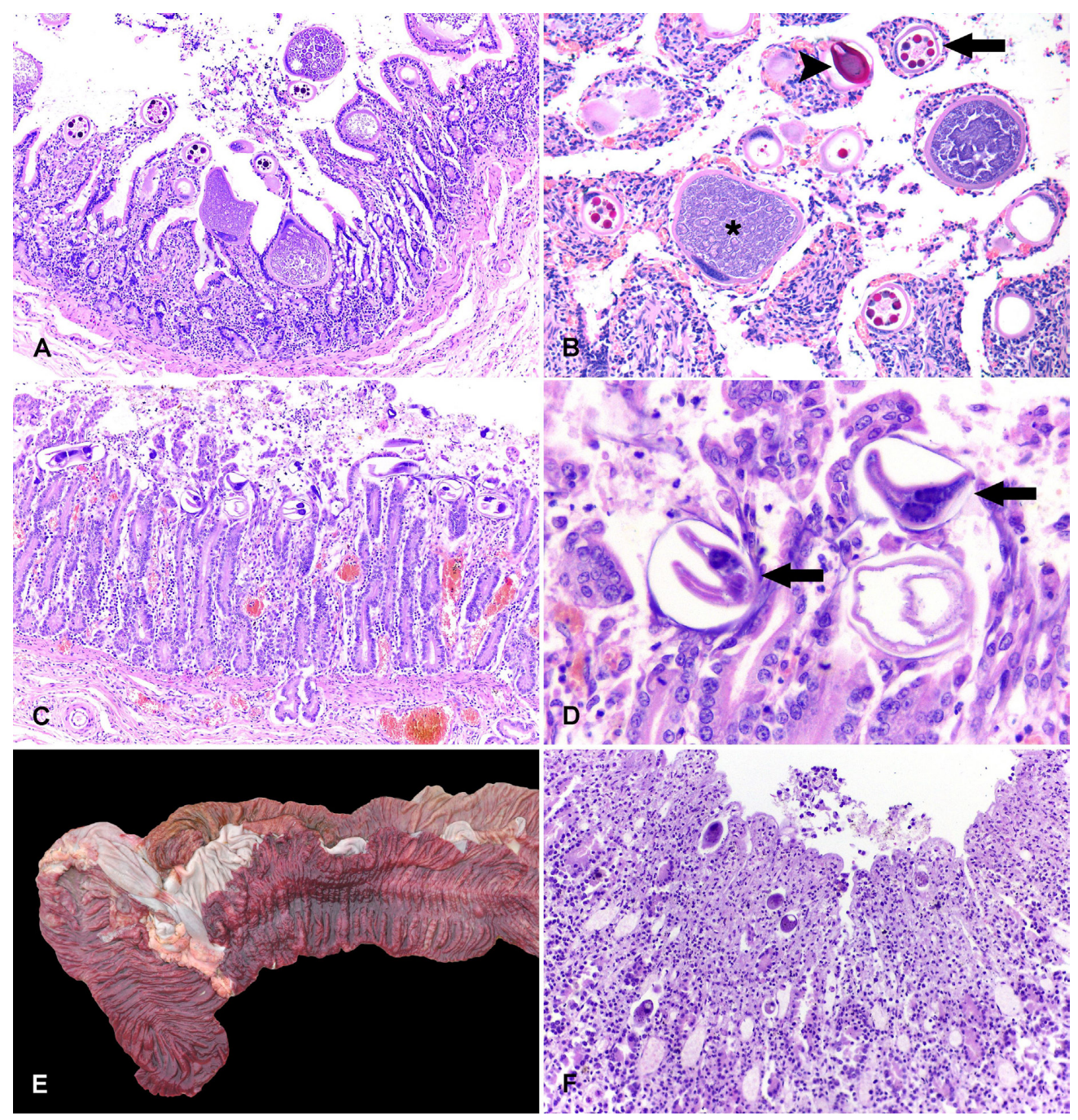

Figure 2. Microscopic findings of Eimeria leuckarti and Strongyloides westeri enteritis (A-D), and gross and microscopic findings of Balantidium coli typhlocolitis (E, F). (A) The villi of the jejunum and ileum are mildly atrophied and have multiple Eimeria parasitic structures at distinct stages (macrogamonts, microgamonts, and oocysts) inside hypertrophied host cells at the apex. Hematoxylin and eosin (H\&E), 100× magnification; (B) Macrogamonts are round and contain multiple peripheral eosinophilic round granules (arrow). Microgamonts are round and contain multiple swirling microgametes inside, which are characterized by pinpoint basophilic granules (asterisk). Unsporulated oocysts are oval, with a micropyle at one end, an enlarged region at the opposite side, a thick eosinophilic capsule, and a sporoblast with granular eosinophilic material (arrowhead). H\&E, 200× magnification; (C) S. westeri enteritis shows severe atrophy of the villi with numerous encysted parasitic structures at the base of the villi. H\&E, 100× magnification; (D) These have external unevenly spaced cuticular ridges, a thin eosinophilic cuticle, with platymyarian musculature, a uninucleate large intestine with granular dark pigment in the cytoplasm, and a paired genital tract often containing embryonated eggs (arrow). H\&E, 400× magnification; (E) B. coli typhlocolitis is grossly characterized by diffusely reddened mucosa of the cecum and ventral large colon; (F) The mucosa of the large colon and cecum present superficial necrosis associated with multiple oval parasitic structures covered by cilia on the surface (trophozoites of B. coli). H\&E, 200× magnification. 
(4-20 $\mu \mathrm{m})$. Microgamonts were round, measured up to $190 \mu \mathrm{m}$ in diameter, and contained multiple swirling masses of microgametes characterized by pinpoint basophilic granules. Unsporulated oocysts were oval $(70 \times 50 \mu \mathrm{m})$, with a micropyle at one end, an enlarged region at the opposite side, a thick eosinophilic capsule and a sporoblast with granular eosinophilic material (Figure 2B). Surrounding these structures there was moderate fibrous connective tissue proliferation and mild inflammatory infiltration of eosinophils in the lamina propria.

S. westeri enteritis was grossly characterized by abundant liquid and fetid content in the small intestine, which had on the mucosa multiple irregular red areas. In addition, mesenteric lymphatic and blood vessels were evident. Microscopic examination revealed that the segments of the duodenum to ileum had severe atrophy of the villi with numerous encysted parasitic structures at the base of the villus, measuring from $45 \times 60 \mu \mathrm{m}$ (transverse cut surface) to $190 \times 30 \mu \mathrm{m}$ (longitudinal cut surface) (Figure 2C). These had a characteristic morphology of $S$. westeri (LUCENA et al., 2012), with external unevenly spaced cuticular ridges, a thin eosinophilic cuticle, with platymyarian musculature, a uninucleate large intestine with granular dark pigment in the cytoplasm, and a paired genital tract often containing embryonated eggs (Figure 2D). Numerous embryonated eggs were also observed retained in the epithelial tunnels at the base of the villi. The mucosa also showed marked hyperemia, hemorrhage, and moderate inflammatory infiltration of lymphocytes, neutrophils, and eosinophils.

$B$. coli typhlocolitis associated with cyathostominae in horse \#10 was grossly characterized by a diffusely reddened serosa of the cecum and ventral large colon. Both had the mucosa diffusely and markedly reddened and intermixed with multifocal whitish pinpoint areas (Figure $2 \mathrm{E}$ ). In addition, cyanotic mucous membranes and moderate mesenteric lymphadenomegaly were observed. Microscopic examination revealed that the mucosa of the large colon and cecum had superficial necrosis associated with multiple oval parasitic structures covered by cilia on the surface (trophozoites of B. coli; Figure 2F). These trophozoites measured $25 \times 40 \mu \mathrm{m}$ and contained a prominent basophilic macronucleus, multiple micronuclei, occasional clear contractile vacuole, and prominent cytostome. In addition, there was severe inflammatory infiltration of eosinophils, lymphocytes and plasma cells in the lamina propria and submucosa; mild crypt-cell hyperplasia; decreased goblet cells; severe lymphoid hyperplasia; and moderate edema in the submucosa. Rare cut sections of the large intestine had in addition to protozoans, occasional encysted cyathostominae in the mucosa. Mesenteric lymph nodes showed diffuse hyperplasia.

\section{Discussion}

The diagnose in the present cases were obtained by associating the gross and microscopic findings with the observation of parasites inside the mucosa and associated surrounding lesions. Parasitological examinations were performed for identifying cyathostominae species in two cases (horses \#4 and \#5), but no adult parasites were identified, and only L4 parasites were detected. Most pathogenic effects related to cyathostomins arise when the developed L4 parasite emerges from the cysts and into the intestinal lumen (CORNING, 2009), as was observed in three of the cases wherein large numbers of filiform reddish parasites were freely intermixed in abundant liquid intestinal content. Interestingly, these three cases also showed associated mucosal ulceration similar to that reported in a previous study (NIELSEN et al., 2015), suggesting that the mucosal lesions are important in the pathogenesis of this condition, and differing from a previous study which stated that ulceration of the mucosa in these cases is mostly related to the alimentary behavior of adult cyathostomin (REINEMEYER, 1986). Nevertheless, the remaining three cases may have showed a distinct pathogenesis mostly related to the invasion of the mucosa by the parasites, since L3 enter the glands of Lieberkuhn in the large intestine and penetrate the cell at the base (REINEMEYER, 1986), with subsequent development of encysted larvae, and later reduced nutritional metabolism in the intestine (COLLOBERT-LAUGIER et al., 2002).

Clinically, cyathostominae typhlocolitis had diarrhea as a constant finding in all horses, and this was different from the findings of a previous study wherein it was considered variable (PIEREZAN et al., 2009a). Several clinical syndromes may occur with cyathostome infection, including acute protein-losing diarrhea, recurrent diarrhea, rapid weight loss, subcutaneous edema, lethargy, inappetence and variable fecal consistency (MAIR, 2002). In a previous study, cyathostomiasis caused acute diarrhea in three horses, of which only one had a clinical recovery (BODECEK et al., 2010). This study, in which all the horses were younger than 1.5 years old, theorized that foals are more susceptible to severe acute protein-losing diarrhea, while aged horses may present mostly recurrent diarrhea (BODECEK et al., 2010). Previous studies have also shown that foals have less resistance to helminths, with higher mean EPG (SHEFERAW \& ALEMU, 2015), and are thus more susceptible to this condition (PIEREZAN et al., 2009a) because of their as-yet undeveloped immune system (NIELSEN \& LYONS, 2017); these findings are similar to the present findings.

On gross examination, the mucosa of the colon and cecum was markedly thickened with numerous elevated nodules containing tangled filiform parasites, similar to those previously described (PIEREZAN et al., 2009a). On histological examination, these nodular lesions had both early and late stages of L 3 and L4 parasites surrounded by an eosinophilic and granulomatous inflammatory infiltrate. Both larval stages were expected to be observed, since are part of the cyathostomins life cycle progression, as has been previously described in juvenile horses infected by a fenbendazole-resistant cyathostominae population (NIELSEN et al., 2015) and in 5 horses described in other study (PIEREZAN et al., 2009a). However, early L3 parasites were observed only in the mucosa, and this can may be related to the acute clinical course of the present cases with a concomitant mucosal invasion by these stages (CORNING, 2009), followed by the emergence of immature parasites to the intestinal lumen (REINEMEYER, 1986). Corroborating these data, previous studies have shown that early stage L3 parasites may be observed exclusively in the lamina propria if horses are treated with a less efficient anthelmintic (fenbendazole), while late stage L3 and L4 parasites may be observed in both the mucosa and submucosa (NIELSEN et al., 2015), similarly to the observations in the present study. Moreover, previous studies showed that L3 and L4 
parasites are more likely to be encysted in the mucosa than in the submucosa (BODECEK et al., 2010; STEUER et al., 2018), but these works may be related to the same species of cyathostomes, since some species may prefer to occupy a particular tissue level (REINEMEYER, 1986). Indeed, our cases may be related to similar cyathostome species, as the distribution of late stage L3s and L4 parasites was predominantly in the mucosa/submucosa, which is similar to the distribution described in other foals (NIELSEN \& LYONS, 2017). Still, prolonged persistence of larvae in the third stage may occur, since these stages molts to the L4 within the tissue cyst (REINEMEYER, 1986).

The presence of larvae on gross and histopathological examinations is essential to obtain a final diagnosis of cyathostomiasis, since fecal egg counts are often zero or very low during larval cyathostomiasis, with the passage of many L4 with the feces (LOVE et al., 1999; LYONS et al., 2000; REINEMEYER, 1986). However, identification at the species level was not possible in the present study, since foals less than 1 year old mostly present juvenile nematodes (KUZMINA et al., 2011), with no adult parasites present, as in the present study. This probably occurred due to the fact that cyathostomiasis is related to the emergence of immature parasites that do not reproduce yet (REINEMEYER, 1986), and species identification relies mainly on adult parasites rather than larval stages (CORNING, 2009), because the larval stages possess fewer morphological characters than do adult worms (KHARCHENKO et al., 2009). Additionally, the size of cyathostome populations, mostly adult stages, may vary with the age of the horse, exposure history, management, use of anthelmintics, and the level of nutrition (REINEMEYER, 1986). Another potential differential pathological diagnosis would be typhlocolitis and lymphadenitis caused by Rhodococcus equi; however, unlike in the present cases, the mucosal lesions would have been observed in both the small and large intestines with purulent elevated ulcers (pyogranulomas), and the mesenteric or colonic lymph nodes would have been obliterated by edema and caseous/purulent foci (UZAL et al., 2016).

Cyathostominae typhlocolitis was observed mainly in the spring (4/6 cases) and autumn (2/6 cases) in the present study, unlike in a previous study in which most of the cases occurred in the winter and autumn (PIEREZAN et al., 2009a). This seasonal difference may be explained by the subtropical climate of the region, with marked differences in temperature and rainfall between the seasons (COPAERGS, 2018), since the development of larvae is directly related to the environmental temperature, with lower temperatures being very lethal to preinfective larval stages (REINEMEYER, 1986). Thus, in the warmer summer months, the larvae are inhibited and may reemerge in the autumn, while the opposite may occur in the cooler months (winter), with the larvae reemerging as the weather warms up in the spring (BAUDENA et al., 2000; REINEMEYER, 1986).

Strongyloides spp. are small nematodes that infect all species of domestic animals, and their larvae typically establish and persist within tunnels in the small intestine (GARDINER \& POYNTON, 2006; UZAL et al., 2016). The pattern of lesions, which is related to the morphological features of the parasite and the involvement of the duodenum/ileum, was characteristic of $S$. westeri infection in this case. This species mostly infects foals (LUCENA et al.,
2012) and may be fatal in heavily infected animals (UZAL et al., 2016), as was observed in horse \#8. Outbreaks usually occur in the summer (LUCENA et al., 2012); however, since lactation is an important pathway for $S$. westeri infection (LYONS et al., 1973) and since foals are usually born in the spring in the study area, these factors were probably related to the fatal enteritis observed in horse \#9. Nevertheless, the occurrence of $S$. westeri enteritis in horses seems to be low so far, most likely because of the use of highly effective drugs, such as benzimidazoles and ivermectin (LYONS et al., 1993). Despite that, a recent study showed an overall elevated prevalence of patent $S$. westeri infections in foals in the USA, probably resulting from the diminished use of ivermectin owing to recent resistance in Parascaris equorum (LYONS \& TOLLIVER, 2014), which may increase the overall importance of that parasite in horses in the near future.

The clinical findings observed in our study in S. westeri parasitism (chronic diarrhea, apathy, fever and dehydration) are similar to those previously described in an outbreak in Brazil (LUCENA et al., 2012), and are related to the gross and microscopic lesions caused by this parasite, wherein heavy parasite loads may persist for at least 10 weeks in foals (BOWMAN, 2014). The gross findings were mainly characterized by multifocal red areas on the mucosa and the accumulation of fluids in the intestinal lumen. This loss of fluids most likely occurred because of numerous encysted parasitic structures occupying the base of the villi; these may also be related to the atrophy of the villi, as described in previous studies (LUCENA et al., 2012).

E. leuckarti is the only valid species of Eimeria in equids (DUBEY \& BAUER, 2018), and oocyst detection has been widely reported through fecal examinations, mainly in foals (SOUZA et al., 2009; DUBEY \& BAUER, 2018; FIGUEIREDO et al., 1993). However, as shown in the present study, it may also occur in older horses (HIRAYAMA et al., 2002). Nevertheless, the present study reinforces the fact that post-mortem examinations may provide useful diagnostic insights in these cases, since the morphological features of unsporulated oocysts are similar to those described through coproscopic techniques (SOUZA et al., 2009). Clinically, this infection may present with or without clinical signs of lower alimentary tract disorders (HIRAYAMA et al., 2002), as in the present study wherein horse \#7 had few clinical signs other than severe cachexia. A minor proportion of horses excreting E. leuckarti organisms may present with temporary diarrhea (STUDZIŃSKA et al., 2008). This probably led to the accumulation of abundant liquid content in the small intestine in the present case, similarly to previous descriptions (REPPAS \& COLLINS, 1995), and most likely resulted in severe dehydration, serous fat atrophy, and death.

On microscopic examination, Eimeria organisms (macrogamonts, microgamonts, and oocysts) are frequently found in the cytoplasm of hypertrophied host cells in the lamina propria at the tips of the villi of the jejunum and ileum (HIRAYAMA et al., 2002). However, microgamonts may be mistaken for schizonts because of their size; even though these have not yet been identified in naturally infected equids (DUBEY \& BAUER, 2018). The parasites may also be found in the extracellular spaces surrounded by macrophages and lymphocytes (HIRAYAMA et al., 2002), but this was not observed in the present study, and only minor changes were evident. 
In this study, $B$. coli typhlocolitis was diagnosed mainly on the basis of the association between the gross and microscopic findings. Morphology has been the basis for species identification, and, thus, $B$. coli was identified by its large size, ovoid shape, dense curved macronucleus, adjacent small micronucleus, contractile vacuoles, and the presence of cilia on the surface (HEADLEY et al., 2008; SCHUSTER \& RAMIREZ-AVILA, 2008; UZAL et al., 2016). In horses, it has previously been associated with an abrupt onset of colic and severe hemorrhagic and eosinophilic colitis without any obvious simultaneous primary infection (HEADLEY et al., 2008). This differs from the present case wherein rare cut sections of cyathostominae were also observed in the mucosa of the large intestine, suggesting that this infection probably favored $B$. coli invasion and proliferation in the large intestine of horse \#9. A similar pathogenesis has been proposed for abomasal and lymphatic balantidiasis in the Barbary sheep (Ammotragus lervia), which was associated with a previous coccidial development of Eimeria spp. in the epithelial lining of the intestine (CHO et al., 2006).

$B$. coli infection may have three clinical manifestations: asymptomatic, chronic infection with non-bloody diarrhea, and fulminant balantidiasis with mucoid and bloody stools (SCHUSTER \& RAMIREZ-AVILA, 2008). The latter seems to be the case in horse \#9, which showed gross lesions mainly characterized by hemorrhagic typhlocolitis. In support of this theory, the parasite was also considered pathogenic since it was observed invading the mucosa and elicited a predominantly necrotic and eosinophilic inflammatory response, as reported in previous studies (HEADLEY et al., 2008).

Horse \#10 was infected by multiple parasites, including helminths ( $S$. westeri and cyathostomins) and protozoans. Mixed infection by helminths could be attributed to the fact that these roundworms have direct life cycles, with their free-living larvae having similar bionomics (MATTO et al., 2015).

\section{Conclusions}

Fatal parasite-induced enteritis and typhlocolitis are important causes of death in horses, especially in foals aged less than 1.5 years old in Southern Brazil. Cyathostominae typhlocolitis was the main condition diagnosed, followed by E. leuckarti enteritis, S. westeri enteritis and B. coli colitis.

\section{Acknowledgements}

This work was supported by Conselho Nacional de Desenvolvimento Científico e Tecnológico (CNPq) and Coordenação de Aperfeiçoamento Pessoal de Nível Superior (CAPES).

\section{References}

Baker JR, Ellis CE. A survey of post mortem findings in 480 horses 1958 to 1980: (1) causes of death. Equine Vet J 1981; 13(1): 43-46. http:// dx.doi.org/10.1111/j.2042-3306.1981.tb03448.x. PMid:7238480.

Baudena MA, Chapman M, French D, Klei T. Seasonal development and survival of equine cyathostome larvae on pasture in south Louisiana.
Vet Parasitol 2000; 88(1-2): 51-60. http://dx.doi.org/10.1016/S03044017(99)00198-3. PMid:10681022.

Bodecek S, Jahn P, Dobesova O, Vavrouchova E. Equine cyathostomosis: case reports. Vet Med 2010; 55(4): 187-193. http://dx.doi.org/10.17221/88/2010VETMED.

Bowman DD. Georgis' parasitology for veterinarians. 10th ed. St. Louis: Elsevier; 2014.

Brasil. Ministério da Agricultura, Pecuária e Abastecimento - MAPA. Revisão do estudo do complexo do agronegócio do cavalo [online]. Brasília: MAPA; 2016 [cited 2019 Mar 3]. Available from: http://www.agricultura. gov.br/assuntos/camaras-setoriais-tematicas/documentos/camaras-setoriais/ equideocultura/anos-anteriores/revisao-do-estudo-do-complexo-doagronegocio-do-cavalo

Cho HS, Shin SS, Park NY. Balantidiasis in the gastric lymph nodes of Barbary sheep (Ammotragus lervia): an incidental finding. J Vet Sci 2006; 7(2): 207-209. http://dx.doi.org/10.4142/jvs.2006.7.2.207. PMid:16645350.

Collobert-Laugier C, Hoste H, Sevin C, Dorchies P. Prevalence, abundance and site distribution of equine small strongyles in Normandy, France. Vet Parasitol 2002; 110(1-2): 77-83. http://dx.doi.org/10.1016/S03044017(02)00328-X. PMid:12446091.

Conselho Permanente de Agrometeorologia Aplicada do Estado do Rio Grande do Sul - COPAERGS. Prognósticos e recomendaçóes para o periodo Set/Out/Nov de 2018 [online]. Porto Alegre: COPAERGS; 2018. (Boletim de Informaçóes; no. 51) [cited 2019 Mar 3]. Available from: http://agromet. cpact.embrapa.br/copaergs/Boletim51_COPAAERGS_Setembro2018.pdf

Corning S. Equine cyathostomins: a review of biology, clinical significance and therapy. Parasit Vectors 2009; 2(Suppl 2): S1. http://dx.doi. org/10.1186/1756-3305-2-S2-S1. PMid:19778462.

Dubey JP, Bauer C. A review of Eimeria infections in horses and other equids. Vet Parasitol 2018; 256: 58-70. http://dx.doi.org/10.1016/j. vetpar.2018.04.010. PMid:29887031.

Figueiredo LMA, Sequeira JL, Bandarra EP, Gandolfi W. Intussuscepção ceco-cólica em equino associada a infecção por Eimeria leuckarti. Rev Bras Parasitol Vet 1993; 2(1): 71-72.

Gardiner CH, Poynton SL. An atlas of metazoan parasites in animal tissues. Washington: Armed Forces Institute of Pathology; 2006. 63 p.

Gordon HM, Whitlock HVA. A new technique for counting nematode eggs in sheep faeces. J Counc Sci Ind Res 1939; 12(1): 50-52.

Headley SA, Kummala E, Sukura A. Balantidium coli-infection in a Finnish horse. Vet Parasitol 2008; 158(1-2): 129-132. http://dx.doi. org/10.1016/j.vetpar.2008.08.013. PMid:18922641.

Hirayama K, Okamoto M, Sako T, Kihara K, Okai K, Taharaguchi $S$, et al. Eimeria organisms develop in the epithelial cells of equine small intestine. Vet Pathol 2002; 39(4): 505-508. http://dx.doi.org/10.1354/ vp.39-4-505. PMid:12126156.

Instituto Brasileiro de Geografia e Estatística - IBGE. Tabela 3939: efetivo dos rebanhos por tipo de rebanho [online]. Brasília: IBGE; 2017 [cited 2019 Mar 3]. Available from: https://sidra.ibge.gov.br/Tabela/3939\#resultado

Kharchenko V, Kuzmina T, Trawford A, Getachew M, Feseha G. Morphology and diagnosis of some fourth-stage larvae of cyathostomines (Nematoda: Strongyloidea) in donkeys Equus asinus L. from Ethiopia. Syst Parasitol 2009; 72(1): 1-13. http://dx.doi.org/10.1007/s11230-0089152-8. PMid:19048404. 
Kuzmina TA, Tolliver SC, Lyons ET. Three recently recognized species of cyathostomes (Nematoda: Strongylidae) in equids in Kentucky. Parasitol Res 2011; 108(5): 1179-1184. http://dx.doi.org/10.1007/s00436-0102160-z. PMid:21107866.

Love S, Murphy D, Mellor D. Pathogenicity of cyathostome infection. Vet Parasitol 1999; 85(2-3): 113-122. http://dx.doi.org/10.1016/S03044017(99)00092-8. PMid:10485358.

Lucena RB, Fighera RA, Barros CSL. Foal mortality associated with Strongyloides westeri parasitism. Pesq Vet Bras 2012; 32(5): 401-404. http://dx.doi.org/10.1590/S0100-736X2012000500007.

Lyons ET, Drudge JH, Tolliver SC. On the life cycle of Strongyloides westeri in the equine. J Parasitol 1973; 59(5): 780-787. http://dx.doi. org/10.2307/3278405. PMid:4744516.

Lyons ET, Drudge JH, Tolliver SC. Larval cyathostomiasis. Vet Clin North Am Equine Pract 2000; 16(3): 501-513. http://dx.doi.org/10.1016/ S0749-0739(17)30092-5. PMid:11219346.

Lyons ET, Tolliver SC, Drudge JH, Granstrom DE, Collins SS. Natural infections of Strongyloides westeri: prevalence in horse foals on several farms in central Kentucky in 1992. Vet Parasitol 1993; 50(1-2): 101-107. http://dx.doi.org/10.1016/0304-4017(93)90010-K. PMid:8291184.

Lyons ET, Tolliver SC. Prevalence of patent Strongyloides westeri infections in Thoroughbred foals in 2014. Parasitol Res 2014; 113(11): 4163-4164. http://dx.doi.org/10.1007/s00436-014-4088-1. PMid:25149063.

Mair T. Chronic diarrhea. In: Mair T, Divers T, Ducharme N, editors. Manual of equine gastroenterology. 1st ed. London: WB Saunders; 2002. p. $432-436$.

Marcolongo-Pereira C, Estima-Silva P, Soares MP, Sallis ESV, Grecco FB, Raffi MB, et al. Equine diseases in Southern Brazil. Pesq Vet Bras 2014; 34(3): 205-210. http://dx.doi.org/10.1590/S0100-736X2014000300002.

Matto TN, Bharkad GP, Bhat SA. Prevalence of gastrointestinal helminth parasites of equids from organized farms of Mumbai and Pune. J Parasit Dis 2015; 39(2): 179-185. http://dx.doi.org/10.1007/s12639-013-03154. PMid:26063996.

Nielsen MK, Loynachan AT, Jacobsen S, Stewart JC, Reinemeyer DW, Horohov DW. Local and systemic inflammatory and immunologic reactions to cyathostomin larvicidal therapy in horses. Vet Immunol Immunopathol 2015; 168(3-4): 203-210. http://dx.doi.org/10.1016/j. vetimm.2015.09.009. PMid:26429413.

Nielsen MK, Lyons ET. Encysted cyathostomin larvae in foals: progression of stages and the effect of seasonality. Vet Parasitol 2017; 236: 108-112. http://dx.doi.org/10.1016/j.vetpar.2017.02.013. PMid:28288752.
Pereira JR, Vianna SS. Gastrointestinal parasitic worms in equines in the Paraíba Valley, State of São Paulo, Brazil. Vet Parasitol 2006; 140(3-4): 289295. http://dx.doi.org/10.1016/j.vetpar.2006.03.036. PMid:16687215.

Pierezan F, Rissi DR, Oliveira JC Fo, Lucena RB, Tochetto C, Flores $\mathrm{MM}$, et al. Granulomatous enteritis associated with larval cyathostomiasis in horses in Rio Grande do Sul, Brazil. Pesq Vet Bras 2009a; 29(5): 382386. http://dx.doi.org/10.1590/S0100-736X2009000500004.

Pierezan F, Rissi DR, Rech RR, Fighera RA, Brum JS, Barros CSL. Necropsy findings related to the cause of death in 335 horses: 19682007. Pesq Vet Bras 2009b; 29(3): 275-280. http://dx.doi.org/10.1590/ S0100-736X2009000300015.

Reinemeyer CR. Small strongyles: recent advances. Vet Clin North Am Equine Pract 1986; 2(2): 281-312. http://dx.doi.org/10.1016/S07490739(17)30717-4. PMid:3527374.

Reppas GP, Collins GH. Eimeria leuckarti in three foals. Aust Vet J 1995; 72(2): 63-64. http://dx.doi.org/10.1111/j.1751-0813.1995.tb15333.x. PMid:7779037.

Schuster FL, Ramirez-Avila L. Current World Status of Balantidium coli. Clin Microbiol Rev 2008; 21(4): 626-638. http://dx.doi.org/10.1128/ CMR.00021-08. PMid:18854484.

Sheferaw D, Alemu M. Epidemiological study of gastrointestinal helminths of equines in Damot-Gale district, Wolaita zone, Ethiopia. J Parasit Dis 2015; 39(2): 315-320. http://dx.doi.org/10.1007/s12639-013-0352-z. PMid:26064026.

Souza PN, Bomfim TC, Huber F, Abboud LC, Gomes RS. Natural infection by Cryptosporidium sp., Giardia sp. and Eimeria leuckarti in three groups of equines with different handlings in Rio de Janeiro, Brazil. Vet Parasitol 2009; 160(3-4): 327-333. http://dx.doi.org/10.1016/j. vetpar.2008.10.103. PMid:19117684.

Steuer AE, Loynachan AT, Nielsen MK. Evaluation of the mucosal inflammatory responses to equine cyathostomins in response to anthelmintic treatment. Vet Immunol Immunopathol 2018; 199: 1-7. http://dx.doi. org/10.1016/j.vetimm.2018.02.011. PMid:29678224.

Studzińska MB, Tomczuk K, Sadzikowski AB. Prevalence of Eimeria leuckarti in young horses and usefulness of some coproscopical methods for its detection. Bull Vet Inst Pulawy 2008; 52: 541-544.

Uzal FA, Plattner BL, Hostetter JM. Alimentary system. In: Maxie MG, editor. Jubb, Kennedy, and Palmer's pathology of domestic animals. 6th ed. St. Louis: Elsevier; 2016. p. 1-257. (vol. 2). http://dx.doi.org/10.1016/ B978-0-7020-5318-4.00007-3. 